\title{
Figurative aspects suggestive of infectious diseases in the ceramic pots of the pre-columbian Moche culture. Analysis of the ceramics collection in the Larco Museum of Lima, Peru
}

\author{
Sergio Sabbatani ${ }^{1}$, Sirio Fiorino ${ }^{2}$, Roberto Manfredi ${ }^{3}$ \\ ${ }^{1}$ Physician and Infectious Diseases Specialist, Bologna, Italy; \\ 2Unità Operativa di Medicina Interna, Ospedale di Budrio, Azienda USL di Bologna, Italy; \\ ${ }^{3}$ Istituto di Malattie Infettive, Policlinico S. Orsola-Malpighi, Università degli Studi di Bologna, Italy
}

Article received 27 May, 2020; accepted 15 October, 2021

\section{SUMMARY}

The historical-medical and anthropological studies, regarding Mesoamerica and South America, have been mainly focused on the great empires (Inca, Atzec, Maya), while other civilizations have been less investigated and only recently are gaining interest. In general, the paleopathological research provides interesting data to know the type of nutrition and the general environmental conditions as well as to point out some ritual mutilation practices, which were relatively frequent in the pre-Columbian cultures. A lot of civilizations flourished in the South America before the arrival of the Spanish Conquistadores in the new world. In the last years it is progressively increasing the interest for the study of the Moche culture as well as for a deeper knowledge of pathocenosis of infectious diseases in the Moche society. Human infectious diseases are known to have a frequent animal origin, in particular from domesticated species, although the species domesticated in the pre-Columbian era were a small number. The purpose of our paper has been to examine the archeological findings suggestive of infectious diseases in artistic ceramic pots, dating back to the Moche period. We examined the iconography of ceramic pots belonging to the collection of the Larco Museum in Lima and reproducing body signs suggestive of infectious diseases. We identified 8 handworks with very interesting features by a medical point of view. In these handworks there are signs and lesions possibly associated with infectious diseases: risus sardonicus, orbital edema, facial nerve palsy, dorsal kyphosis, face and skin lesions. These features are compatible with some infectious diseases, including: syphilis, Bartonella bacilliformis, leishmaniasis, Pott's disease and Chagas disease. A wide discussion about these handworks is provided.

Keywords: Moche, culture, infectious diseases, handwork.

paper fulfils studies aimed to demonstrate findings consistent with infectious disorders, in accordance with the historian Marc Bloch's masterful

\footnotetext{
${ }^{1}$ Pathocenosis is a concept conceived by Mirko Drazen Grmek (Krapina, 9 January 1924 - Paris, 6 March 2000). It represents the set of diseases detectable in a population in a given period and in a specific society. Therefore, Pathocenosis includes a complex of diseases, which vary both quantitatively and qualitatively, in which the frequency of each disease depends on the other disea-

ses or environmental factors.
}

Corresponding author
Sergio Sabbatani
E-mail: sergio.sabbatani@aosp.bo.it
The study of infectious diseases pathocenosis ${ }^{1}$ 1 in the South American region during the preColumbian period is particularly difficult, since no literary evidences are available. However, our 
thoughts ${ }^{2}[1]$. He underlined the historical value of the research about the archeological findings. His works are based on the earlier investigations carried out on buried corpses (mummies) by the palopathologist Armand Ruffer $^{3}$ [2].

By a strictly bio-medical side, thanks to the recent introduction of innovative imaging techniques like the computed tomography (CT), - a non-invasive mode to study mummies - as well as the use of immuno-histochemistry and of bio-molecular laboratory assays (for the search of old DNA sequences), it became possible to carry out very reliable studies on mummies and bone remnants. These bio-medical studies allow to establish with a good approximation the etiology of macroscopic paleopathological pictures, where a diagnostic suspect of an infectious disease was already present [3-5].

The historical-medical and anthropological researches, concerning Mesoamerica and South America, have mainly focused their attention on the great empires (Inca, Atzec, Maya), while other cultures only recently have attracted a larger public attention and previously they have been certainly less studied. The understanding of these last cultures represents a significant source of informations from both an anthropological and an historical-archeological point of view. In this geographic context, the paleopathological research gives interesting data to know the type of nutrition and the general environmental conditions as well as to point out some ritual mutilation practices, which were relatively frequent in the preColumbian cultures.

In particular, a forerunner of the paleo-pathological studies of the infectious diseases which have affected the pre-Columbian Peruvian populations of the Pacific coast was Julio César Tello (18801947), who published in the year 1909 his doctorate thesis entitled: La antiguedad de la sifilidis en el Perù [6].

More recently, Altamirano studied several Incan

${ }^{2}$ Marc Léopold Benjamin Bloch (Lyon, 6 July 6, 1886 Lyon, June 16, 1944), was a French historian and army officer. He was a member of the Resistance and he was killed under torture by Nazis.

${ }^{3}$ Sir Marc Armand Ruffer (1859-1917), English-German pathologist, one of the pioneers of the paleopathologic studies and the study of the ancient Egyptian mummies. skulls from Makat-Tampu, where it was possible to demonstrate bone abnormalities associated with leishmaniasis [7].

Of utmost interest is the work published by Cadwallader and Arcein in 2012 [8]. These authors collected the cases of kyphosis which they detected in corps, buried in a cemetery with Nazca cultural affiliation. In relation with these findings, a relevant number of lesions compatible with vertebral body collapses is related to a tubercular disease (Pott's disease). The scientist Ruff was the first to have pointed out this relationship and his studies were realized on Egyptian mummies in Cairo city [2].

In the year 1974, Allison and coworkers published a case of Carrion's disease observed in a buried corpse. This dead body was retrieved in South Peru and belonged to the Huari culture; it is interesting to notice that this individual had been a victim of a ritual sacrifice [9]. In a mummy retrieved in Northern Chile in the year 1979, a case of paracoccidioidomycosis (South-American blastomycosis), has been diagnosed $[10]^{4}$. Gerszten, Allison and Maguir published a paper in 2012, concerning the syphilis, in the journal Pathobiology, expressing this opinion: "At the present time, we are not aware of definitive evidence of T. pallidum in pre-Columbian mummies" [11]. However, the same authors in the year 1994 reported the results of autopsies performed on several mummies. Their article allowed to appreciate inflammatory signs like the sabet-shaped tibias, typical of congenital syphilis, together with skull abnormalities, probably pointing out a prior syphilis [12].

The studies performed on autopsy specimens (livers and spleens), obtained from pre-Columbian mummies, showed that about $6-7 \%$ of samples were tested positive for P. vivax serology. A pigmentation associated with malaria infection was confirmed in $30 \%$ of positive cases [13]. Fur-

${ }^{4}$ This infection is diagnosed only in population clusters of Central and Southern America which today interests men aged 20 to 50 years, mainly coffee coltivation farmers of Colombia, Venezuela, and Brazil. It is estimated that still today around 10 million people are infected. In the mucous-cutaneous form, the lesions usually interest the face and in particular the mucous cutaneous edges of mouth an nose. There is also the swelling of regional lymph nodes, where a necrosis occurs, together with drainage of necrotic material. 


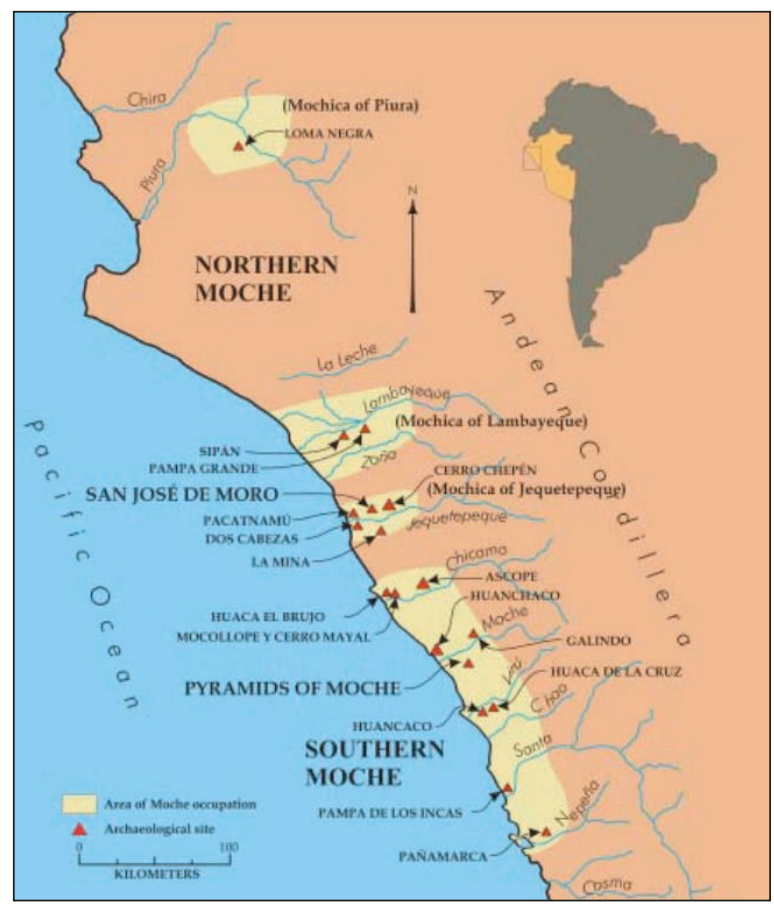

Figure 1 - Regions of the Moche civilization settlement in the coastal region of Northern Peru. In these areas, the Moche population developed a thriving agriculture thanks to irrigation.

thermore, signs of megacolon complication have been found in 9 pre-Columbian mummies. These features are typical and compatible with Chagas disease [14]. Aufderheide and coworkers investigated 238 tissue specimens from pre-Columbian mummies found in archeological sites in Northern Chile and Southern Peru. In $41 \%$ of cases, PCR testing proved positive for an old DNA, belonging to Trypanosoma cruzii [15].

The aim of our research is to assess the representation of features, which may suggest the presence of infectious diseases, through the study of archeological findings (artistic ceramic pots), dating back to the Moche period.

First of all, a brief presentation of the most interesting elements of the Moche culture is needed. During 650 years between the year 200 and the year 850 after Christ, the Moche people, thanks to their patient and skillful work, highly improved the North shore of Peru and adapted it to the human presence. They established a fluorishing agriculture, developed thanks to ingenious irrigation techniques. The valleys close to coasts were irrigated via to the canalization of the water flowing the numerous torrents, which originated from the Andean Cordillera (Figure 1).

The irrigation came also from the extraction of water from the water tables, which were cyclically supplied by the phenomenon of $\mathrm{Nino}^{5}$. It is relevant to specificate that the coast areas of Northern Peru are predominantly desertic, and still today the sole cultivated soil is that which benefits from irrigation.

In the Moche territory the development of agriculture, with the consequent large availability of food, enabled a demographical increase. As a direct consequence, some population segments became specialized in novel technological activities: metallurgy and irrigation techniques. Concurrently, also ceramics handcraft was developed, and significant advances occurred in the pottery manufactury, which reached a valuable level of artistic refinement, from a figurative point of view. In particular, the craftmen were attracted by the expressiveness of human types (faces) depicted on pots and tried to pick some original expressive elements. The Moche ceramics are recognized among the most varied and expressive of the entire American continent. The technology used is the mold technique and this knowledge allowed a "series production" of some shapes, although we have to precise that the Moche ceramics show a large variety of proposed shapes and themes. These handworks are representative of some important themes of the social life and in particular of sexual attitudes, which are depicted by the Moche artists in a very realistic way. In the different classified collections, at least 500 ceramic pieces are detectable and are referred to sexual themes; it seems interesting to report that anal coitus is the most represented, although the majority of depicted couples are heterosexual. This observation may indicate an educational willingness to exert a demographic control, also consider-

${ }^{5}$ El Niño-Southern Oscillation, also known with the acronym ENSO (El Niño-Southern Oscillation), is a periodic climate situation characterized by an elevated warming of the Central-Southern Western and Eastern Pacific Ocean (Latin America) during the months of December and January meanly every five years, but varying between 3 and 7 years. This phenomenon causes floodings of the directly interested areas, but also drought in outer zones and other kind of climatic perturbations which might vary at every presentation. 
ing that the Moche territory, altough well irrigated, was surrounded by the Andean Cordillera and the Sierra at East, and also between the different areas which became fertile thanks to the human work, large portions of desert were present.

From a medicine history point of view, of upmost interest are the ceramics (pots) where facial lesions are reproduced, together with a stylization of the body which presumably indicate infectious diseases.

As we anticipated, the demographic increase of the Moche population induced a proportional surplus of workforce, which made the realization of important works possible. These expansive projects were concentrated on the enlargement of irrigation facilities, but also on the construction of religious buildings. In these last settings, built by sapient architects - using the bricks - the Moche painters flaunted their interesting painting art, by which they offered a realistic representation of the religious and politic life of their society [5] (Figure 2).

Most of the data we can know on the discovery of the historical importance of Moche population is due to the archeological research carried out by Rafael Larco Hoyle in the first half of the past century. In this perspective, the first and key searches have been conducted in the Lambayeque valley (Ipan), in the Moche valley (Huaca del Sol and Huaca de la Luna), at San José de Moro (valle de Jequetepeque), and in the site named Huaca El Brujo (Chicama valley) [5] (Figure 1).

As already mentioned, the founder of archeology in the Northern area of Peru was Rafael Larco Hoyle $^{6}$. He successfully identified and characterized the Moche population as a unique, centralized society, which took its origins in the Moche and Chicama valleys [16, 17]. In brief, the Moche population had its capital in the Moche valley with its political and religious centres in two sites named: Huaca del Sol${ }^{7}$ e Huaca de la Luna. In this place a noteworthy aristocratic élite estab-

${ }^{6}$ Rafael Carlos Víctor Constante LarcoHoyle (Hacienda Chiclín, Trujillo, May 18.1901 - Lima, October 23, 1966) acted as an archeologist, researcher, writer, agriculture engineer, and historian.

${ }^{7}$ This temple is one of the most important archeological sites which are located close to the Cerro Blanco mountain, in the coastal desert not far from the modern city of Trujillo.

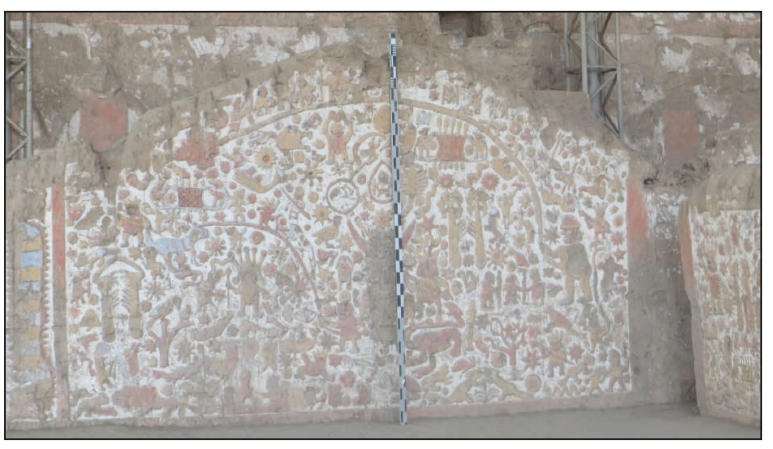

Figure 2 - Murales in the Huaca del sol.

lished its home, and was able to concentrate in its hands many power attributes. In particular, this élite succeeded in dominating the population by a well-balanced synthesis of coercive modes, together with well calibrated cultural contents. As far as we know, the mentioned aristocracy could count on a military arm, on a linked and an effective political ideology and a complex religious liturgy, which encompassed ritual mass processions [5].

As anticipated, the Moche population built impressive temples, where the priests of the cult celebrated religious cerimonies, with a massive presence of the population. During these ceremonies, also human sacrifices were conducted, usually young boys and girls belonging to noble families. The selection of these predicted victims was decided on the basis of astral calculations. All this liturgic machinery legitimized a centralized statal political system of the imperial type, exerted by economical and political means.

We have to specify that the political organizations of Moche population arised in the different coastal valleys in the North and in the South of the country, approximately in the same time, but their subsequent development was characterized by a different and original process, which gave origin to handicrafts and which changed over time, following a distinct evolutive advancement [5]. During the last decades, different researchers concluded that the Moche territory should be divided in two different regions: Moche of South and Moche of North, corresponding to different political entities $[18,19]$.

Let's come to another aspect we need to consider. Human infectious diseases are known to have a frequent animal origin, in particular from domes- 
ticated species. Concerning the use of animals for transportation and production of meat, milk, and wool, differently from other regions of the planet, in the Americas the species domesticated in the pre-Columbian era were a small number. According to the most credible hypothesis, the early anthropization ("colonization") of the Americas occurred between 15,000 and 12,000 years ago, when the regions of Alaska and Siberia should be connected by an isthmus which during the glaciation acted as a "bridge" between Asia and America ${ }^{8}$. These men, migrating from central Siberia, found a continent where big mammalians had the time and the possibility to expand their large herds, which grazed in large grasslands.

The new inhabitants, instead of trying to domesticate the meek animal species, continued to behave as unbridled hunters, to solve their food needs. Because of this reason - here summarized in brief - the animal domestication was more limited in the Americas compared with other regions of the planet where, starting from the Mesolithic and even more during the Neolithitic and in the pre-historic era, humans started domesticating animals for every different need of human development (food or work force).

A relationship about the infectious diseases acquired by human and due to the proximity with animals is not among the objectives of the present study. In synthesis, should the massive development of agriculture be one of the most important causes of the diffusion of epidemics, the fact of becoming resident and sedentary led the early farmers to live in proximity with their waste (a cause of bacterial growth and spread), as well as with

${ }^{8} \mathrm{~A}$ different model of anthropization of the America otherwise supposes that the migration fluxes of the humans in the era of hunter-gatherers were different. These individuals did not arrive via the land but via the sea, around 40,000 years ago. Such a hypothesis is based on recent researches and discoveries, like that of 33 skulls in the Southern California, which had genetic marks nearer to individuals originating in Southern Asia, compared with ones from Siberia. However, the first anthropization of America remains a subject of relevant debate among the scientists. However, in both the represented situations, the first inhabitants of the America did not have already domesticated animals in Europe and Asia, and the concept of domestication was lacking in their culture, when they reached the new continent. the parasites of domesticated animals (the main source of micro-organism transmission).

Furthermore, the irrigation techniques and the creation of fish farms made easier the life to molluscs, which can transmit worms like Schistosomas. In particular, the early agriculture farms with cereal deposits made easier the development of rodents, which are important carriers of infectious diseases. Finally, the deforestation to create cultivable fields near human villages, led to an ideal habitat for anopheles' mosquitoes, and therefore for the spread of malaria ${ }^{9}$.

Some notes on the domestication of two animal species (Llamas and Guinea Pigs) in the context of South America

The development of agriculture in the Neolithic allowed a proportional demographic improvement, during times not always coincident and in different geographical areas of the planet. Following the increased availability of foodstuff, the population density also increased. In fact, the progressive introduction of agriculture forced people, usually prone to hunt and harvest, to progressively become sedentary.

Concerning the domestication of animals in South America in the pre-Columbian era, apart from dogs whose domestication seems to go back to around 20,000 years b.C., given its defined utility in the activity of hunting and procuring food, we have evidences related only to two animal species: the Llama (with the related species Alpaca) and the Guinea Pig. The Llamas were domesticated around the year 3,500 b.C. and were employed by the South American pre-historian men for transportation and for their mantle, which was useful in the cold Andean climate. Concerning Guinea Pigs, they are considered one of the most important food resources in Peru, Colombia and Ecuador, also in the pre-Incas era.The Peruvian archeologists affirm that the domestication of Guinea Pigs may be started around the year 5,000 b.C. in the plateau regions of South Peru and Bolivia.The researches conducted at Chavin de Huantar in the plateaus of Central-Northern Peru clearly document the breeding

${ }^{9}$ With regard to these subjects and the relationship among the domestication of animals, the anthropization of the Americas and the occurrence of infectious disease epidemics, we recommend the reknown volume by Jared Diamond: Armi, Acciaio e Malattie [20]. 
of Guinea Pigs since the year 900 b.C. Significant documents demonstrating the use of Guinea Pigs as a food in the Moche valley go back to the year 200 a.C., while archeological evidences of breeding Guinea Pigs as a food in the coastal plan of Ecuador goes back to the year 500 a.C.

The ceramics representing sick people at the Larco museum of Lima

Correa-Trigoso performed an accurate analysis of the Moche ceramic (pots) collection of the Larco Museum, published in the year 2017, selecting 337 pieces of notable quality. All these pots show faces which are representative of the diseases which afflicted the Moche population [5]. The Author identified even 17 different types, representing abnormalities, which have been divided into two specific groups: diseae- ses and body abnormalities. In the Table 1 we re-propose the table written by Correa-Trigoso and part of his publication, with the Author's permission. The images of some Moche ceramics, depicting sick individuals, have been kindly granted by the Cultural Institution of the Larco Museum and are published in our paper. The following paragraph includes 8 pictures, reproducing body signs suggestive of infectious diseases.

Iconography of ceramic pots belonging to the collection of the Larco Museum in Lima and reproducing body signs suggestive of infectious diseases

In this paragraph, eight pictures (Figures 3-10) of ceramic pots, belonging to the collection of the Larco Museum in Lima, are reported. Each of

Table 1 - The table is integrally drawn from the article entitled: "Presencia de paleopatologias en las representaciones Mochica: Un estudio da la coleccion ceràmica del Museo Larco. Horizonte de la Ciencia 7(12) 43-60, 2017" by Correa-Trigoso and it is published with his kind permission. Author has identified 17 different types of pathological conditions and abnormalities, probably afflicting Moche population. He has classified them into two specific subsets: diseases and body alterations. In the first group the Author has recognized: endogenous diseases, including lumbar kyphosis, squinting, cleft lip, exophthalmos, facial paralysis, club foot, siamese twins, crouzon syndrome, seckel syndrome, exogenous diseases, including Bartonellosis, Leishmaniasis, Syphilis; multiple diseases, including visual deficit and obesity.

\begin{tabular}{|c|c|c|c|c|c|c|}
\hline \multirow{2}{*}{\multicolumn{3}{|c|}{ Paleopathologies }} & \multirow{3}{*}{$\begin{array}{c}N \\
12 \\
\end{array}$} & \multirow{3}{*}{$\begin{array}{c}\% \\
2.97 \\
\end{array}$} & \multicolumn{2}{|c|}{ Total } \\
\hline & & & & & $N$ & $\%$ \\
\hline \multirow[t]{14}{*}{ Diseases } & \multirow[t]{9}{*}{ Endogenous } & Lumbar kyphosis & & & \multirow[t]{9}{*}{49} & \multirow[t]{9}{*}{12,13} \\
\hline & & Squinting & 3 & 0.74 & & \\
\hline & & Cleft lip & 6 & 1.49 & & \\
\hline & & Exophthalmus & 2 & 0.50 & & \\
\hline & & Facial paralysis & 5 & 1.24 & & \\
\hline & & Club foot & 1 & 0.25 & & \\
\hline & & Siamese twins & 7 & 1.73 & & \\
\hline & & Crouzon syndrome & 1 & 0.25 & & \\
\hline & & Seckel syndrome & 12 & 2.97 & & \\
\hline & \multirow[t]{3}{*}{ Exogenous } & Bartonellosis & 1 & 0.25 & \multirow[t]{3}{*}{147} & \multirow[t]{3}{*}{36,39} \\
\hline & & Leishmaniasis & 140 & 34.65 & & \\
\hline & & Syphilis & 6 & 1.49 & & \\
\hline & \multirow[t]{2}{*}{ Multiple } & Visual deficit & 63 & 15.59 & \multirow[t]{2}{*}{115} & \multirow[t]{2}{*}{28,47} \\
\hline & & Obesity & 52 & 12.87 & & \\
\hline \multirow{3}{*}{\multicolumn{2}{|c|}{ Body alterations }} & Club foot & 8 & 1.98 & \multirow[t]{3}{*}{93} & \multirow[t]{3}{*}{23,02} \\
\hline & & $\begin{array}{l}\text { Lower limb } \\
\text { Mutilations }\end{array}$ & 67 & 16.58 & & \\
\hline & & $\begin{array}{l}\text { Upper limb } \\
\text { Mutilations }\end{array}$ & 18 & 4.46 & & \\
\hline \multicolumn{3}{|l|}{ Total } & 404 & 100,00 & 404 & 100 \\
\hline
\end{tabular}




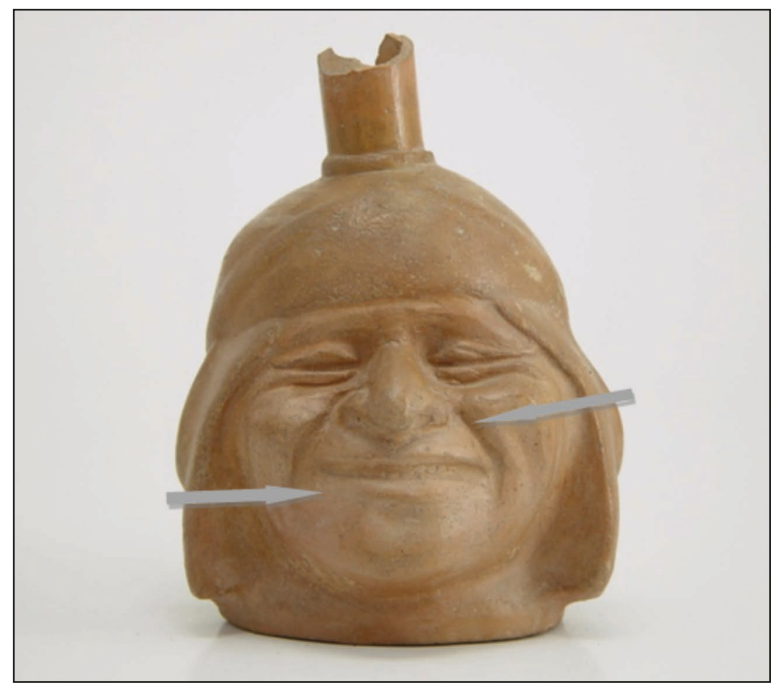

Figure 3 - Moche ceramic pot (ML000426a) with a facial expression which reminds the typical risus sardonicus. This sign is a characteristic feature of tetanus. As it is well-known, in the risus sardonicus we have a prolonged spasm of facial muscles (grey arrows) and in this condition the eyebrows are raised (grey arrow). In ancient times and in the Mediterranean area, the risus sardonicus could also be a consequence of the ingestion of the so called "sardonic herb" which, according to Pausania, was the hemlock; presently the experts think that this tetanus-like spasm of toxic origin was more probably caused by the euphorbia herb, which is also present in the tropical regions of both Africa and the Americas.

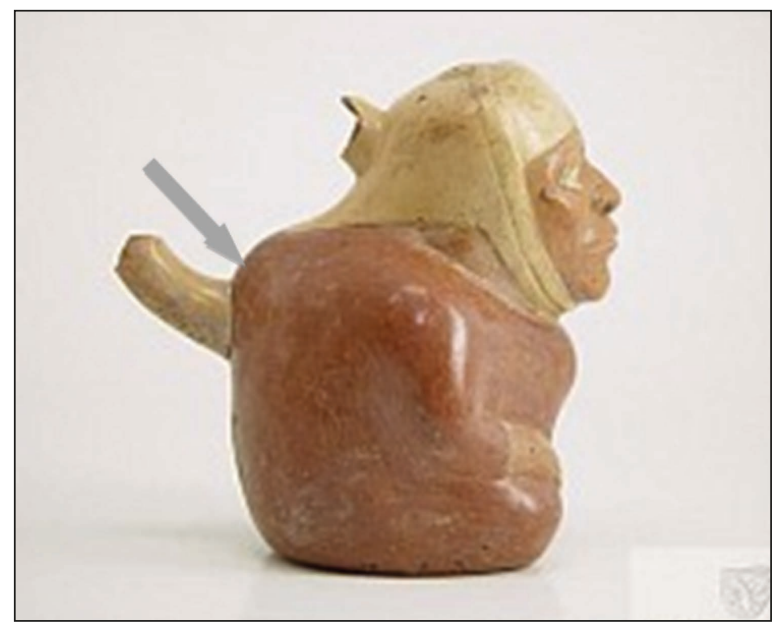

Figure 4 - Moche ceramic pot (ML002747/Arroyo2013). An evident dorsal kyphosis (grey arrow) is represented, probably indicating a vertebral collapse secondary to bone tuberculosis (Pott's disease). Among subjects buried in a cemetery explored near Nazca (Centra-Southern Peru), numerous bone remnants showing macroscopic vertebral collapses have beeen retrieved (8).

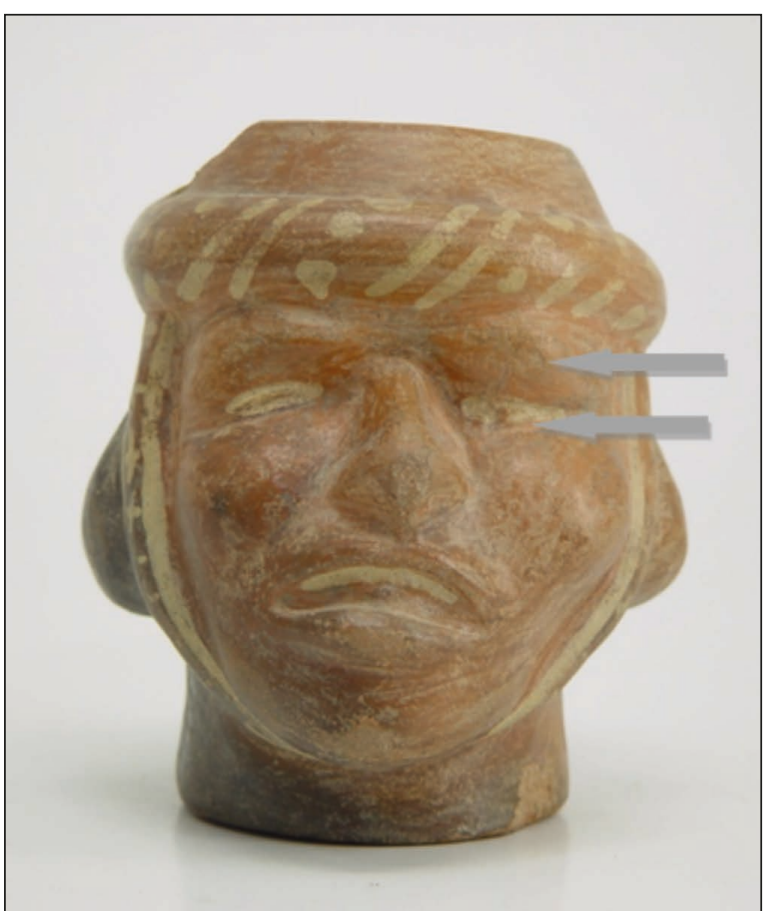

Figure 5 - Moche ceramic pot (ML000471a). Note the great eyelid swelling (edema) of the left eye eyebrows (grey arrows). In this ceramic piece the Moche craftsman is thought to have reproduced the face of a subject with an exaggerated phlogosis of the left eye (grey arrows). This typical clinical sign has been desribed for the first time by Romaña. In the Chagas disease (South American trypanosomiasis), caused by the protozoan Tripanosoma cruzii, when the hematophagous bug stings the skin, the patient becomes infected. The triatomine bedbugs usually live in the mud, in the straw, and in the huts of the rural areas of Mexico, South America, and Central America. These bugs are usually active overnight, while during the daytime they hide in the cracks of the walls or of the roof. The mode of infection is the following: the insect stings the exposed areas of the skin (predominantly the face), releasing the Tripanosoma parasites during the hematic meal. The bedbug defecates near to the bite, the fecal material irritates the skin causing itching, the patient by scratching favours the entry of parasites into the body through the conjunctives and once the Trypanosoma cruzii parasite enters the organism it proliferates in the different infected organs. The Romaña sign presents 1-2 weeks after the inoculation, usually the patient has no pain, but the orbital edema may extend towards the cheekbone. From a clinical point of view, neck Iymphadenopathies and fever may be associated for some weeks. In the South American area Fornaciari and co-workers confirmed the ancient presence of chagas disease through paleo-pathological studies, conducted in pre-Columbian mummies [3, 4]. 
these photos refers to a probable infectious disease, including the possible presence of:

a) a prolonged spasm of facial muscles, a characteristic sign of tetanus (Figure 3);

b) a vertebral collapse secondary to bone tuberculosis, known as Pott's disease (Figure 4);

c) an inflammation of the left eye, typical clinical signs of the Chagas disease, caused by the protozoan Tripanosoma cruzii (Figure 5);

d) face lesions caused by a bacterium, known as Bartonella bacilliformis, this disease is defined, Carrion disease or Peruvian wart or Oroya's fever (Figure 6);

e) left facial nerve palsy, due to the edema of the nerve, resulting from a viral infection. Several viruses may cause peripheral facial palsy, including herpesviruses, Coxsackievirus, Cytomegalovirus, Adenovirus, Epstein-Barr virus, virus mumps and rubella viruses as well as influenza B virus (Figure 7);

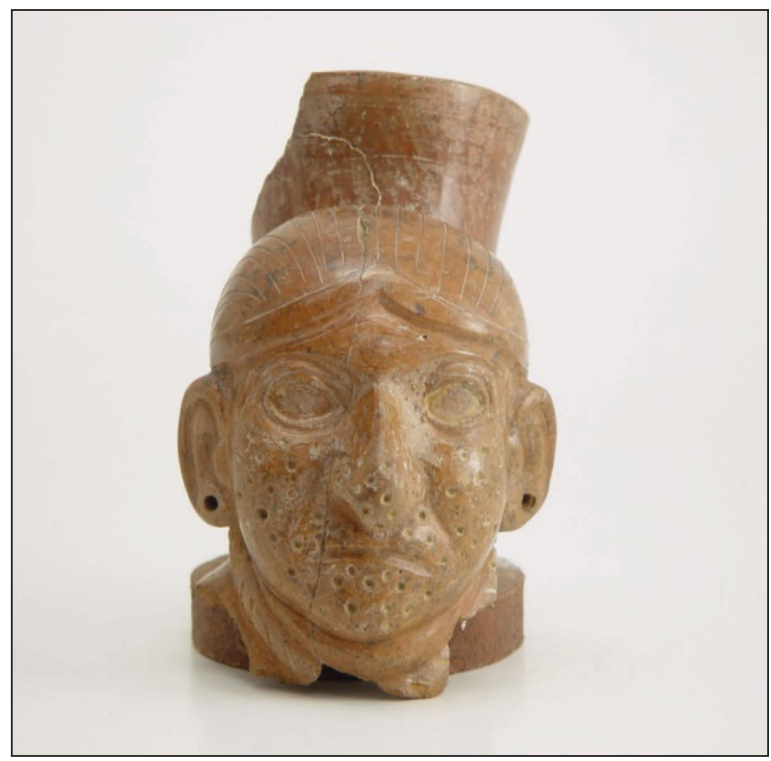

Figure 6 - Moche ceramic pot (ML002643a). In this handwork the face lesions may be caused by bartonellosis, known as Carrion disease or Peruvian wart, or Oroya's fever. This is a bacterial infection caused by Bartonella bacilliformis. The Oroya's fever appears after the initial exposure, while the Peruvuan wart appears after the healing of the primary infection. These diseases are endemic in the Andean regions of Colombia, Ecuador and Peru. The infections are transmitted to men by diptera insects of the genus Phlebotomus. In Southern Peru a buried corpse with a paleo-pathological diagnosis of Peruvian wart has been found [9]. f) first and second stage of luetic lesions, with skin lesions, involving the surface of the lower abdomen and the cutaneous area between the two lower limbs (Figure 8);

g) face lesions due to leishmaniasis, the form caused by Leishmania brazilensis being observed in Central and South America and in its mucous cutaneous variant is associated with deforming and relevant face ulcerations, usually near to mouth and nose (Figure 9);

h) an inflammatory lesion at the neck area interested by an evident yellowish circle-like lesion, which could indicate the presence of purulent material (Figure 10).

The aetiological agents and the most important signs and symptoms are also reported for each disease.

In conclusion, the archeological retrieval of these relavant ceramic objects of the Moche culture in Northern Peru, their classification by studying

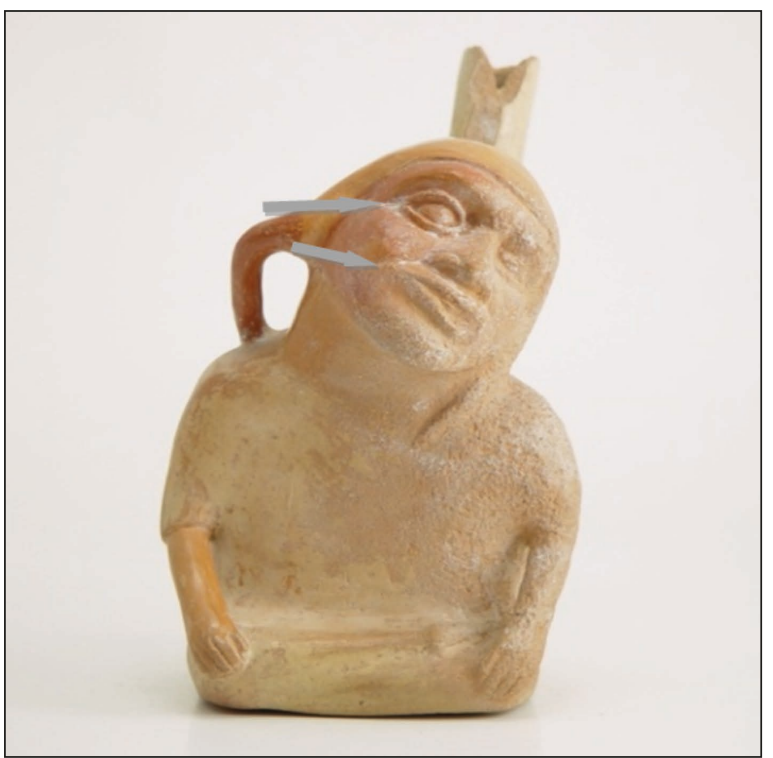

Figure 7 - Moche ceramic pot (ML002735a). In this piece we presume that the artist intended to represent a left facial nerve palsy (grey arrows). The idiopathic facial nerve palsy is due to the edema of the nerve, related to the pathogesis of a viral infection. The herpseviruses are frequently responsible of peripheral facial palsy, followed by other viruses including Coxsackievirus, Cytomegalovirus, Adenovirus, Epstein-Barr virus, virus mumps and rubella viruses as well as influenza $B$ virus. 


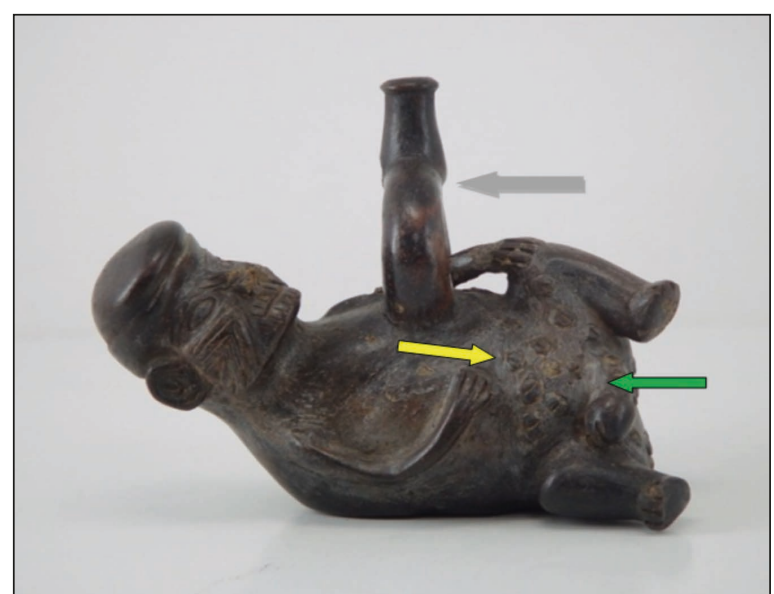

Figure 8 - Moche ceramic pot (ML004300a/Diez 2016). We presume that the handwork represents first and second stage of luetic lesions. It is noteworthy that the artist thought to point out a relationship with the sexual activity. In fact, in this representation the hole for the leakage of liquid content is positioned on the anterior surface of the abdomen (yellow arrow), differently from other ceramic pots and the skin lesions, suggestive of a luetic infection, involve the surface of the lower abdomen (grey arrows) and are localized between the two lower limbs (green arrow). Paleo-pathological studies have documented the presence of this treponemal disease in Peru since many years [6].

their origins, as well as the presentation at the Larco Museum of Lima, allow to shed light on the elevated cultural level of this interesting example of pre-Columbian civilization. The presentation of a small gallery of ceramic pots representing different humans affected by pathogical conditions which seem typical of some well-known infectious diseases, allows us to better define the pathocenosis of this region of South America, referring in particular to the epidemiology of the time preceding the Spanish colonization. In the future, the development of archeological studies, together with the availability of further findings and with the deserved exchange of significant informations among archeologists, medicine historians and paleo-pathologists will largely contribute to a comprehensive cultural advancement in this fascinating knowledge. This approach should be addressed not only to academic world and to the specialists of this field, but also to a larger audience.

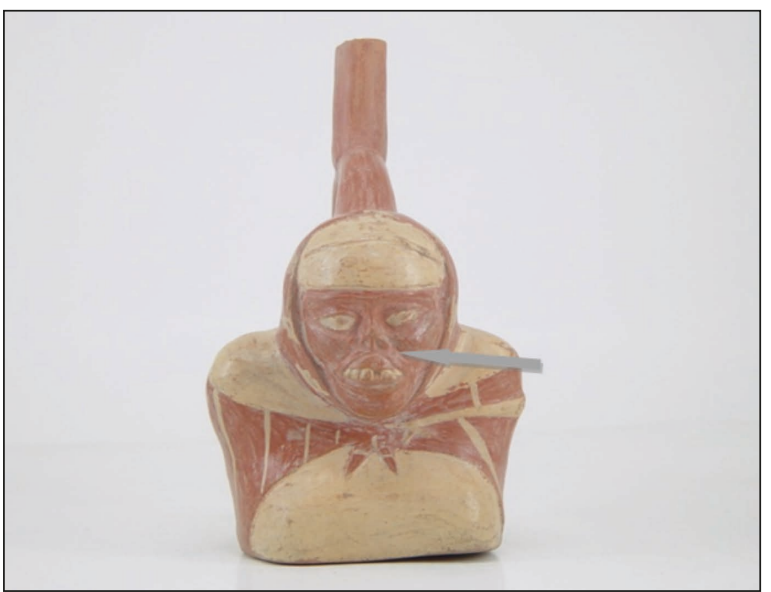

Figure 9 - Moche ceramic pot (ML122990a/Weiss1943). We presume that the artist in his handwork has presented face lesions due to leishmaniasis (grey arrow). Different forms of leishmaniasis in relation with their geographical distribution may be recognized. The form due to Leishmania brazilensis is very frequent in Central and South America, and in its mucous cutaneous variant is associated with deforming and relevant face ulcerations, usually near to mouth and nose. Typically, at the onset, ulcerative mucosal lesions are observed. They tend to worsen, do not resolve spontaneously and become frequently super-infected by bacteria colonizing the mouth. The consequences are frequent and severe mutilations involving also nose cartilages. In the pre-Columbian era, the leishmaniasis has been documented through the examination of bone remnants belonging to Incas subjects, who lived in the Makat - Tampu region (central Perù) [7, 21].

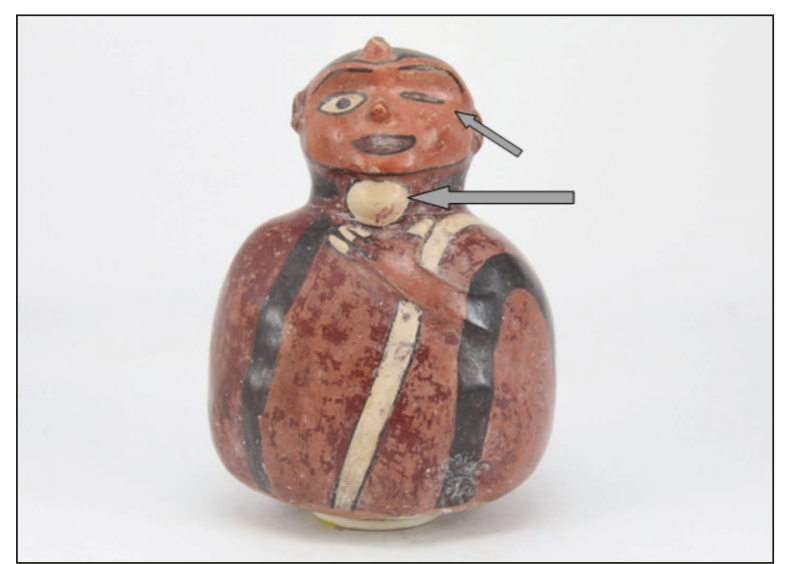

Figura 10 - Moche ceramic pot (ML040370a). In this piece we presume that the artisan has presented an evident inflammatory lesion at the neck (grey arrow), with the left hand which indicates an evident yellowish circle-like area. This picture could point out the presence of purulent material. Note also that the left eye is closed, due to an intense inflammatory process. 


\section{Acknowledgments}

The Authors thank

- the curators of the Larco Museum in Lima: Doctor Patricia Aragaki, Doctor Giannina Bardales, Doctor Juan José Callirgos for the kind and generous collaboration they gave us;

- the Archaeologist Dr. Denis E. Correa-Trigoso for the authorization to publish the table, in its originality, included in his article "Presencia de paleopatologìas en las representaciones Mochica: An estudio da la coleccion ceràmica of the Larco Museum." Horizonte de la Ciencia 2017; 7 (12), 43-60;

- the images depicting Moche ceramic vases, exhibited in the Larco Museum in Lima, are published upon formal request to the Cultural Institution of Larco Museum, which granted authorization;

- the image reproduced in figure 2 is a photograph taken by Dr. Sergio Sabbatani during his recent trip to Peru.

\section{Conflicts of interest}

None to declare.

\section{Fundings}

None.

\section{REFERENCES}

[1] Bloch M. Les Rois thaumaturges: etude sur le character sur nature lattribué à la puissanceroyaleparticulièrement en France et en Angleterre, in Publications de la Faculté des lettres de Strasbourg, Strasburgo, 1924.

[2] Sir M.A. Ruffer studies in the paleopatogy of Egypt. University of Chicago Press 1921.

[3] Guhl F, Jaramillo C, Vallejo GA, et al. Isolation of Tryoanosoma cruzi DNA in 4,000-Year-Old Mummified Human tissue From northern Chile. Am J Phys Antr. 1999; 108, 401-7.

[4] Fornaciari G, Castagna M, Viacava P, Tognetti A, Bevilacqua G. Chagas' disease in Peruan Inca mummy. The Lancet. 1992; 339, 128-129.

[5] Correa-Trigoso DE. Presencia de paleopatologìas en las representaciones Mochica: Un estudio da la coleccion ceràmica del Museo Larco. Horizonte de la Ciencia 2017; 7 (12), 43-60.

[6] Tello J. La antiguedad de la sifilidis en el Perù. Lima: UNMSM, Libreria san marti.1909.
[7] Altamirano E. Comprometiendo la estructura Osteo-Facial de las poblaciones humanas del antiguo Perù por la Leishmaniasis Tegumentaria de forma mucosa y su Significato Cultural. Tesis de doctorato. Escolar Nacional de SaudePublica. Fundacao Oswaldo Cruz. Ministéro de Saude. 2000.

[8] Cadwallader L y Arce S. Proyecto de Investigation Arqueològica Samaca. Informe de los trabayos del Campo realizados durante la temporada 2010.Ministero de Cultura. Perù 2012.

[9] Allison MJ, Pezzia A, Gerszten E, Mendoza D. A case of Carrion's disease associated with human sacrifice from the Huari culture of southern Perù. Am J Phys Anthropol 1974; 41, 295-300.

[10] Allison MJ, Gerszten E, Shadomy J, Munizaga J, Gonzales M. Paracoccidiomicosis in a Northen Chilean mummy. Bul NY Acad Med. 1979; 55, 670-83.

[11] Gerszten E, Allison AJ and Maguire B. Paleopathology in South American mummies: a review and new findings. Pathobiology. 2012; 79, 247-56.

[12] Gerszten E, Allison MJ. Paleopathology of infectious diseases in South American mummies. Pathol Int. 1994; 54: 5440.

[13] Allison MJ, Guillen S, Gerszten E, Caldwell N. Plasmodium vivax malaria: a native pre-columbian disease. Modern Pathol 2009; 22: 293A.

[14] Rothhammer F, Allison MJ, Nunez L, Standen V, B. Arriaza. Chagas disease in pre-columbian South Ametrica. Am J Phis Anthropol. 1985; 68, 495-8.

[15] Aufderheide AC, Wilmar S, Madden M, et al. A 9,000-year record of Chagas disease. Proc Natl Acad Sci. 2004; 101, 2034-9.

[16] Larco R. Los Mochicas (Pre Chimu de Uhle y Early Chimu de Kroeber) Sociedad Geografica Americana, Buenos Aires 1945.

[17] Larco R. Cronologia Arqueològica del Norte del Perù. Biblioteca del Museo de Arqueologia Rafael Larco Herrera, Hacienda Chiclìn. Sociedad Geogràfica Americana, Buenos Aires 1948.

[18] Bawden G. The Moche. Blackwell, Oxford 1996.

[19] Donnan CB. Moche. En: Andean Art at Dumbarton Oaks, edita dopor Elizabeth Hill boone, Tomo 1, pp. 123-162. Dumbarton Oaks Research library and Collection. Washington D.C. 1996.

[20] Diamond J. Armi, Acciaio e Malattie. Breve storia del mondo negli ultimo tredicimila anni. Editore Einaudi Torino,1998.

[21] Altamirano-Enciso AJ et all. Sobre a origen e dispensaodosleishmaniasis cutanea e mucosa com base emfontshistoricaspre e pos-colombianas. Historia - Ciéncias Saude. 2003; 10 (3), 853-82. 